\title{
Notes on the Pontederiaceae names described in Vellozo's Flora fluminensis
}

\author{
Marco Octávio de Oliveira Pellegrini ${ }^{1,2,3}$
}

\begin{abstract}
Notes on the Pontederiaceae names described in Vellozo's Flora fluminensis

The names of Pontederiaceae described by Vellozo in his Flora fluminensis are here revised, with an orthographical correction, two lectotypes and one epitype designated.

Key words: Aquatic flora, Commelinales, Eichhornia, Heteranthera, Rio de Janeiro
\end{abstract}

\section{Introduction}

Vellozo's Flora fluminensis is a monumental work and the first one edited by a Brazilian botanist on our country's flora (Cervi \& Rodrigues 2010). With funding of the Portuguese Empire, Flora fluminensis was a relevant part of the "Portuguese Philosophical Travels" that took place during the XVIII century. This Empire conducted several scientific expeditions across its world-wide domains with two campaigns in the Brazilian territory, with one of them being coordinated by Friar José Mariano da Conceição Vellozo (Damasceno 1977; Pataca 2011).

Flora fluminensis has been widely neglected since its publication due its historically difficult access and tortuous publishing history. It is also worth mentioning that at the time of its publication Vellozo's work was considered non-scientific, thus being highly depreciated by the academic community (Borgmeier 1961; Carauta 1969, 1973; Valle 1985). Combining this context with the general downgrading of taxonomy by the academic community, many plant groups lack recent floristic and taxonomic treatments (Funk 2006). This is also true for most aquatic plant families (Paz \& Bove 2007), and Pontederiaceae is no exception. The group has been extensively studied under its reproductive and evolutionary aspects, but few papers are recorded on taxonomy, especially dealing with their poorly resolved generic limits (Graham et al. 1998; Gomes 2000; Ness et al.
2011). For these reasons, little attention was ever given to the names of Pontederiaceae published by Vellozo (1829). These names were only featured in two national floras (Horn 1987a, 1987b), but completely out of the context of the Rio de Janeiro state flora or of a nomenclatural revision. This paper is part of a series dealing with the nomenclatural problems of the Commelinales names in Vellozo's Flora fluminensis (Aona-Pinheiro et al. 2014; Pellegrini et al. 2015; Pellegrini \& Forzza in press; Pellegrini \& Carvalho in press).

\section{Original specimens and Typification}

The original specimens collected by Vellozo were sent to the Museu Real de Lisboa between 1797 and 1798 (Hamy 1908; Borgmeier 1937). In addition to the specimens Vellozo placed in Lisboa, Hamy (1908) referred to 246 Vellozo specimens arranged in two separate batches (117 and 129 specimens) that were stated to have arrived in Portugal, with the first batch (consisting of 117 specimens) being sent to Paris (Bocage 1862). Nevertheless, those specimens were expropriated during the Napoleonic invasion of Portugal in 1808 and nothing is known about the current whereabouts of Vellozo's original collection (Lima 1995; Cervi \& Rodrigues 2010; Pastore 2013). Thus, making the iconographies of Flora fluminensis the best option for lectotypes and reviewing the described taxa (Carauta 1969; Mello Filho 1975; Cervi \& Rodrigues 2010; Pellegrini et al. 2015).

\footnotetext{
${ }^{1}$ Universidade Federal do Rio de Janeiro, CCS, Inst. Biologia, Av. Carlos Chagas Filho 373, Interbloco B/C, Ilha do Fundão, 21941-902, Rio de Janeiro, RJ, Brazil.

${ }^{2}$ Instituto de Pesquisas Jardim Botânico do Rio de Janeiro, R. Pacheco Leão 915, 22460-030, Rio de Janeiro, RJ, Brasil.

${ }^{3}$ Author for correspondence: marcooctavio.pellegrini@gmail.com
} 
Considering the abovementioned scenario, the names of Pontederiaceae described by Vellozo are here revised, with two lectotypes and an orthographical correction. An epitype was designated when the original plate was insufficient to apply a name to the given species with certainty. The species are presented here in the same order as that of Vellozo's Flora fluminensis.

\section{Taxonomy}

1. Heteranthera reniformis Ruiz \& Pavón, Fl. Peruv. 1: 43, pl. LXXI. 1798.

Buchosia aquatica Vell., Fl. flumin.: 33. 1829. Lectotype (designated here): [illustration] Original plate on parchment of "Flora fluminensis" in the Manuscript Section of the Biblioteca Nacional of Rio de Janeiro [mss1095062_084] and later published by Vellozo (1831. Fl. flumin. Icon. 1: t. 80). Epitype (designated here): BRAZIL. Rio de Janeiro: Rio de Janeiro, entre o Leblon e a Gávea, fl., 1942, Dionisio s.n. (2 ex RB 57561!). — For an image of the lectotype, see Fig. 1a-b; for an image of the epitype, see Fig. 2.

Nomenclatural notes: According to the Code (McNeill et al. 2012, Art. 60.1) the name Buch'osia consists of an orthographical error, which under the Code (McNeill et al. 2012, Art. 60.10) should be corrected by the suppression of the apostrophe. Although this is a situation of automatic correction, the wrong spelling is still used in scientific publications (Castellanos 1959; Horn 1985, 1987b). Nevertheless, since publications regarding the Pontederiaceae and Vellozo names have been few in the past years, this name has been long forgotten. Thus it is formalized here that the correct name for the genus is Buchosia, over the originally spelled Buch'osia.

Horn (1987a, 1987b) was the first to publish Buchosia aquatica as a synonym of $H$. reniformis, since Horn (1985) represents his unpublished Ph.D. thesis, and by means of the Code is not considered validly published (McNeill et al. 2012, Art. 29.1). The same is valid for all nomenclatural and taxonomical decisions proposed by the author at this time. Despite publishing the new synonym, Horn (1987a, 1987b) failed to lectotypify Vellozo's name in both publications, since he never cited Vellozo's plate. Thus, a lectotype is needed for the proper application of this name, being here designated.

Taxonomical notes: Despite Buchosia being considered a synonym of Heteranthera by Horn (1987a, 1987b), there does not seem to be an agreement over the application of B. aquatica, since it is often disregarded or missing in databases (e.g. eMonocot; The Plant List), being cited only in Tropicos.org. After carefully examining the original plate and description of $B$. aquatica it became clear that there are significant differences between the plant described and illustrated by Vellozo $(1829,1831)$ to the known species of the genus Heteranthera, with respect to reproductive characters. Vellozo's description for Buchosia mentions a 4-locular gynoecium and 4-valved capsules that are unknown for Pontederiaceae (in the family fruits can be a 3-valved capsule or an achene, depending on the genus). These features can be also seen in the plate for Buchosia aquatica (Vellozo 1831, v. 1: t. 80; Fig. 1b). The plate also depicts a multibracteate inflorescence, with bracts of the same size as or bigger than the flowers, actinomorphic flowers and glabrous androecium (Fig. 1a-b). In contrast, $H$. reniformis is known to possess inflorescences subtended by a single bract, zygomorphic flowers and barbate stamens (Horn 1985). Nevertheless, many important vegetative, inflorescence and ecological features match perfectly to those of $H$. reniformis, such as the creeping and amphibious habit, reniform leaf blades with obtuse apex and all flowers opening at the same time (Horn 1985, 1987a, 1987b; Fig. 1a,e), leaving no doubt that it should be considered a synonym of the later.

The incongruence between $B$. aquatica and $H$. reniformis suggests that significant characters were wrongly portrayed for the plant in question. Thus, its lectotype is demonstrably ambiguous and cannot be critically identified for purposes of the precise application of the name. Thus, I apply Article 9.8 of the Code (McNeil et al. 2012), and the selection of an epitype for $B$. aquatica serves to fix the application of this name in accordance with its current usage.

2. Eichhornia azurea (Sw.) Kunth, Enum. Pl. 4: 129. 1843.

Pontederia aquatica Vell., Fl. flumin.: 144. 1829. $\equiv$ Eichhornia aquatica (Vell.) Schltdl., Abh. Naturf. Ges. Halle 6: 177. 1862. Lectotype (designated here): [illustration] Original plate on parchment of "Flora fluminensis" in the Manuscript Section of the Biblioteca Nacional of Rio de Janeiro [mss1198652_168] and later published by Vellozo (1831. Fl. flumin. Icon. 3: t. 164). For an image of the lectotype, see Fig. 1c-d. 

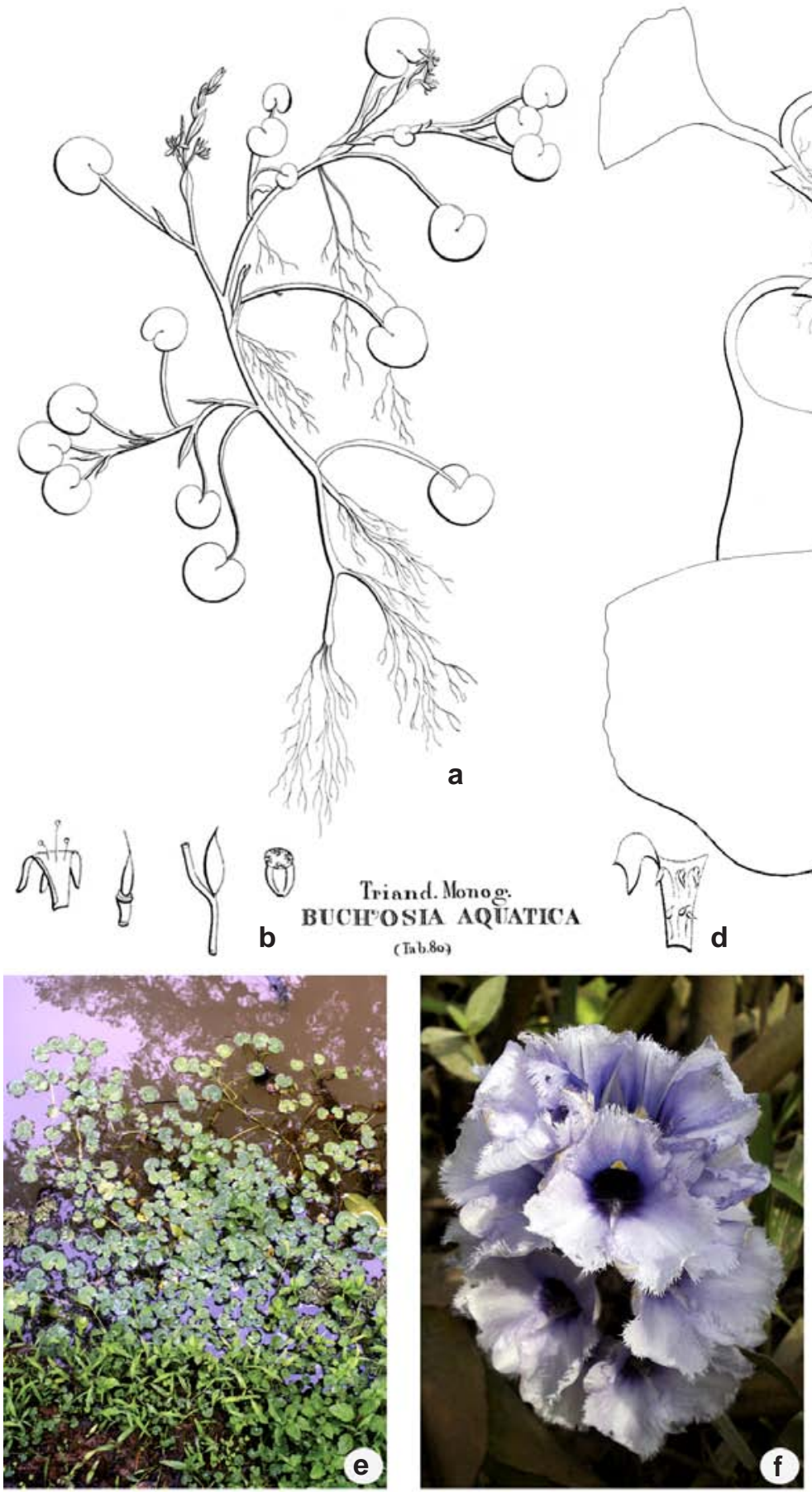

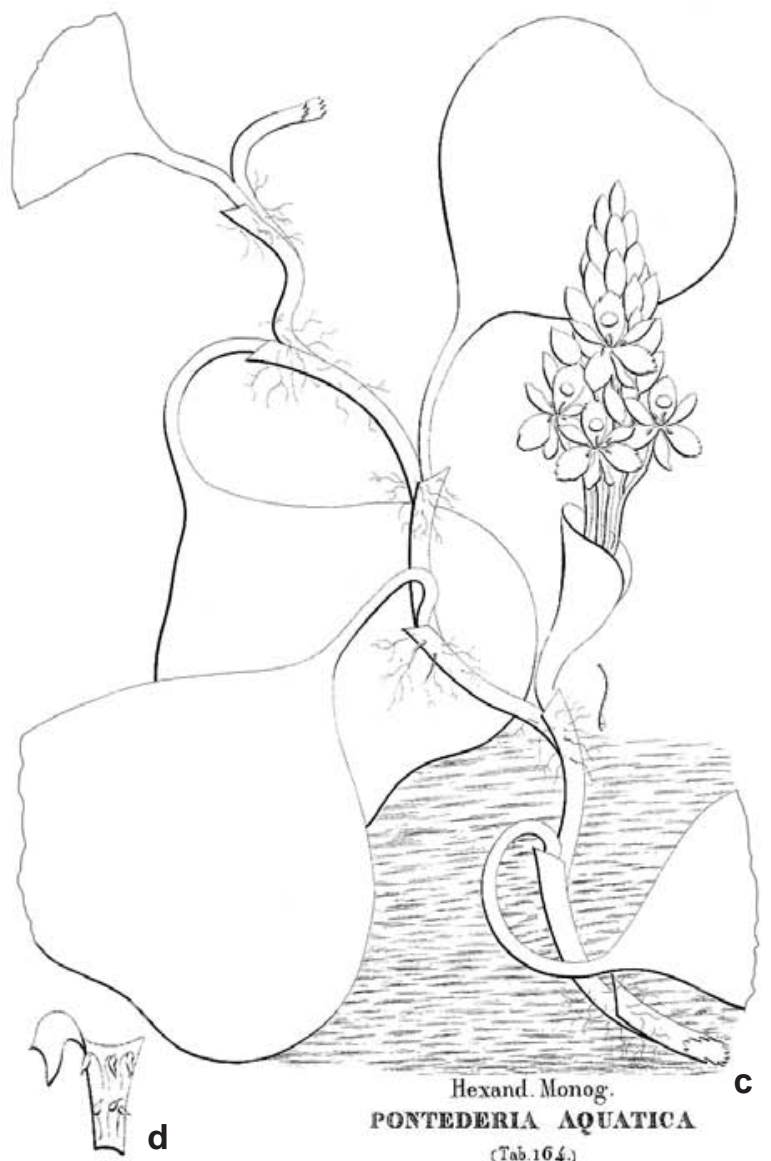

(Tab.164.)

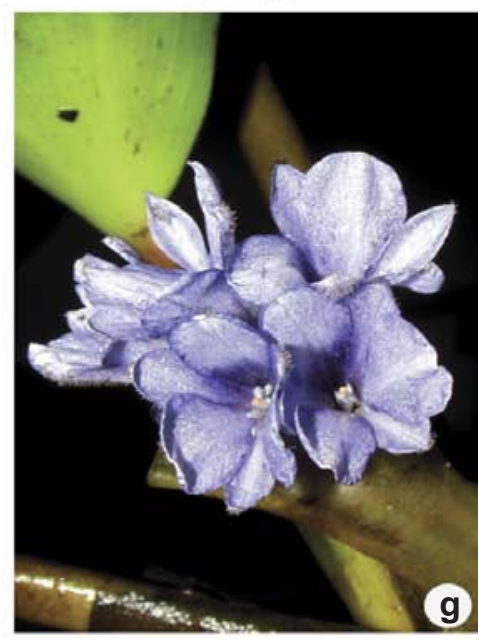

Figure 1 - Original plate of Vellozo's Pontederiaceae names and field photos of the species. a,b. photo of Buchosia aquatica plate from the Biodiversity Heritage Library - a. line drawings of habit, inflorescence and floral characters; b. detail of floral and fruit characters, showing an open flower, the gynoecium and a 4-locular capsule. c-d. photo of Pontederia aquatica plate from the Biodiversity Heritage Library - c. line drawings of habit, inflorescence and floral characters; d. detail of floral characters, showing an open flower. e-g. field photos of Pontederiaceae - e. Heteranthera reniformis; f. Eichhornia azurea; g. Eichhornia heterosperma (A.B.S. de Oliveira 9, Coleção LABEV 6420 - Laboratório de Botânica e Ecologia Vegetal da Universidade Federal do Acre). e. by M.O.O. Pellegrini, f. by A. Cardoso and g. by M. Acosta. 


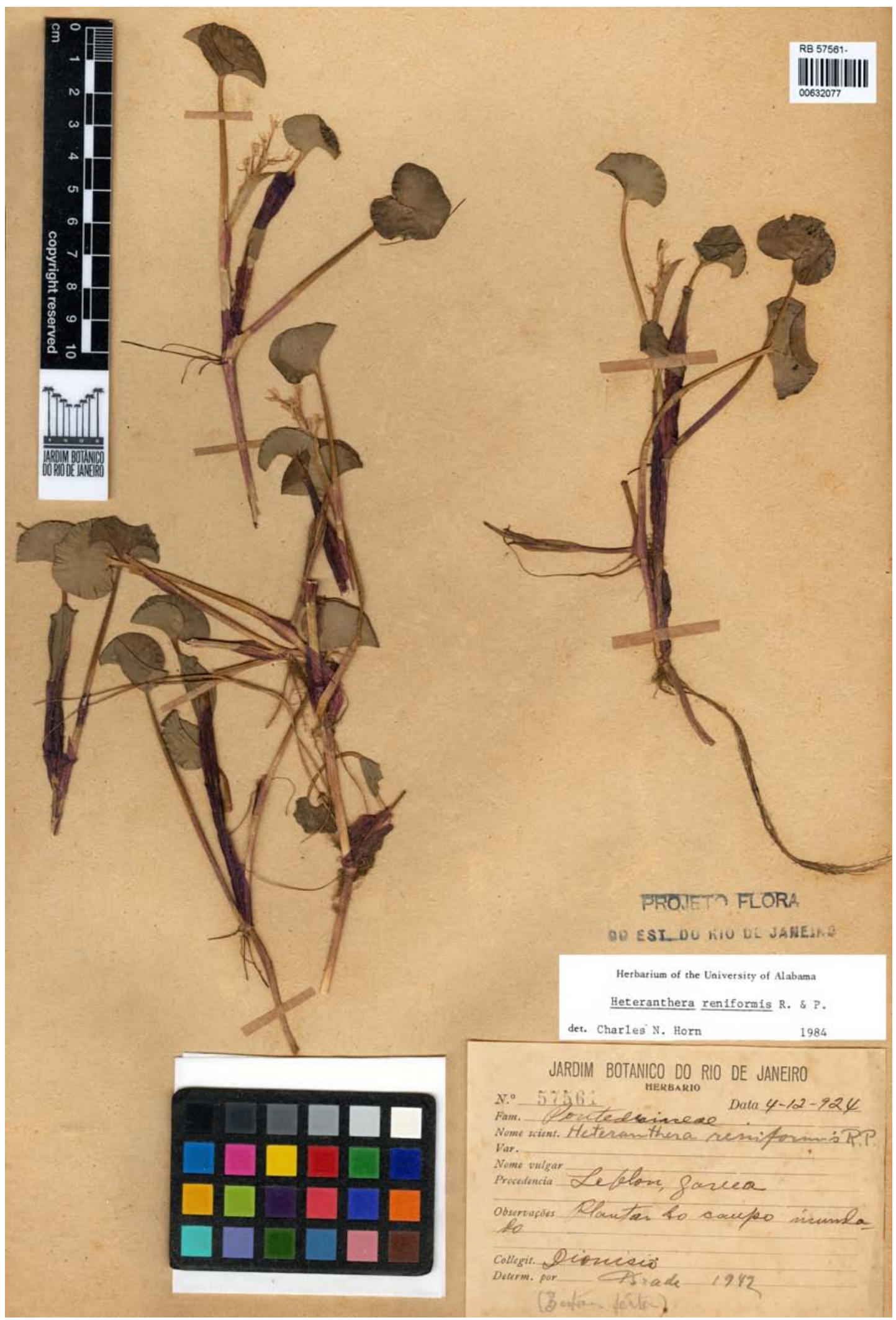

Figure 2- Photo of the epitype of Buchosia aquatica (Dionisio s.n., RB 57561). 
Nomenclatural notes: In the same way as Abovementioned, Horn (1987a, 1987b) was the first to consider Pontederia aquatica a synonym of E. azurea. Nevertheless, he also failed to lectotypify Vellozo's name in both publications. Thus, a lectotype is here designated.

Taxonomical notes: Eichhornia azurea (Fig. 1f) is morphologically similar to $E$. heterosperma Alexander (Fig. 1g), being differentiated from the latter by its monomorphic seeds, puberulous stamens, fimbriate corolla margins and median-superior lobe of the corolla with a yellow spot [vs. dimorphic seeds, glabrous stamens, entire corolla margins and median-superior lobe of the corolla without a yellow spot] (Alexander 1939; Pellegrini pers. obs.). Besides that, only E. azurea, E. crassipes (Mart.) Solms and E. diversifolia (Vahl) Urb. are known to occur in the state of Rio de Janeiro (Amaral et al. 2015).

Vellozo's plate depicts perfectly the growth form, leaf and flower morphology characteristic to E. azurea, with only the stamens being mistakenly illustrated as glabrous (Fig. 1c-d). This is probably due to the fact that Vellozo's plates, especially the details, were mainly drawn based on dried specimens (H.C. Lima, pers. comm.). The description (Vellozo 1829) is impressively detailed when compared with the descriptions presented by botanists contemporary to him (such as Linnaeus), since he describes morphological, ecological and phenological aspects of this species. Thus, that being said, $P$. aquatica should be treated as a synonym of $E$. azurea, with no need to designate an epitype.

\section{Acknowledgments}

The author would like to thank CAPES (Coordenação de Aperfeiçoamento de Pessoal de Nível Superior) for his M.Sc. scholarship. I would also like to thank Luana Silva Braucks Calazans and Fernanda Santos-Silva for suggestions on an early version of the manuscript, RB staff for the photo of Buchosia aquatica's epitype, André Cardoso, Martin Acosta and Herison Medeiros for the pictures of Eichhornia azurea and E. heterosperma, respectively. I would also like to thank Rafael Felipe de Almeida for suggestions on the manuscript and help with the edition of the plates, and three anonymous reviewers for valuable additions on the manuscript.

\section{References}

Alexander, E.J. 1939. In: Smith, A.C. Notes on a collection of plants from British Guiana. Lloydia 2: 170.

Amaral, M.C.E.; Pellegrini, M.O.O. \& Sousa, D.J.L. 2015. Pontederiaceae. In: Lista de Espécies da Flora do Brasil. Jardim Botânico do Rio de Janeiro. Available in $<$ http://floradobrasil.jbrj.gov.br/jabot/floradobrasil/ FB197>. Access on 6 May 2015.

Aona-Pinheiro, L.Y.S.; Bittrich, V. \& Amaral, M.C.E. 2014. Two new species of Dichorisandra (Commelinaceae) from Rio de Janeiro and comments on the two species included in Vellozo's “Flora Fluminensis”. Phytotaxa 184: 223-234.

Bocage, J.V.B. 1862. Ilustrações práticas sobre o modo de colligir, preparar e remeter produtos zoológicos para o Museu de Lisboa. Museu de Lisboa, Lisboa. 96p.

Borgmeier, T. 1937. A história da "Flora Fluminensis" de Frei Velloso. Rodriguésia 9: 77-96.

Borgmeier, T. 1961. A história da "Flora Fluminensis": Documentos. Publicações do Arquivo Nacional 48: 3-21.

Carauta, J.P.P. 1969. A data efetiva da publicação da “Flora Fluminensis”. Vellozia 7: 3-21.

Carauta, J.P.P. 1973. The text of Vellozo's Flora Fluminensis and the effective date of publication. Taxon 22: 281-284.

Cervi, A.C. \& Rodrigues, W.A. 2010. Nomenclatural and taxonomic review of Passifloraceae species illustrated and described by Vellozo in Flora Fluminensis. Acta Botanica Brasilica 24: 1109-1111.

Damasceno, D. 1977. Veloso, J.M.C. Plantas fluminenses descritas por frei Veloso. Anais da Biblioteca Nacional 96: 123-133.

eMonocot. 2010. Version 1.0.2. Available in <http://emonocot.org/>. Access on 20 September 2014.

Funk, V.A. 2006. Floras: a model for biodiversity studies or a thing of the past? Taxon 55: 581-588.

Gomes, V.S. 2000. Levantamento das espécies de Pontederiaceae Kunth nativas do Brasil. Dissertação de Mestrado. Universidade Federal de Pernambuco, Recife. 103p.

Graham, S.W.; Kohn, J.R.; Morton, B.R.; Eckenwalder, J.E. \& Barrett, S.C.H. 1998. Phylogenetic congruence and discordance among one morphological and three molecular data sets from Pontederiaceae. Systematic Biology 47: 545-567.

Hamy, E.T. 1908. La Mission d'Etienne Geoffroy SaintHilaire en Espagne et en Portugal (1808). Histoire et documents. Masson, Paris. 66p.

Horn, C.N. 1985. A systematic revision of the genus Heteranthera (sensu lato; Pontederiaceae). Ph.D. dissertation. University of Alabama, Tuscaloosa. 260p.

Horn, C.N. 1987a. Pontederiaceae. In: Spichiger, R. (ed.). Flora del Paraguay. Vol. 7. Missouri Botanical Garden, Saint Louis. Pp. 7-28. 
Horn, C.N. 1987b. Pontederiaceae. In: Harling, G. \& Andersson, L. (eds.). Flora of Ecuador. Vol. 29. Nordic Journal of Botany, Dinamarca. Pp. 3-20.

Lima, H.C. 1995. Leguminosas da Flora Fluminensis J.M. da C. Vellozo - Lista atualizada das espécies arbóreas. Acta Botanica Brasilica 9: 123-146.

Mello Filho, L.E. 1975. O gênero Heliconia na Flora Fluminensis de Frei José Mariano da Conceição Vellozo. Revista Brasileira de Biologia 35: 331-337.

McNeill, J.; Barrie, F.R.; Buck, W.R.; Demoulin, V.; Greuter, W.; Hawksworth, D.L.; Herendeen, P.S.; Knapp, S.; Marhold, K.; Prado, J.; Prud'Homme Van Reine, W.F.; Smith, G.F.; Wiersema, J.H. \& Turland, N.J. (eds.). 2012. International code of botanical nomenclature (Melbourne Code). Adopted by the Eighteenth International Botanical Congress Melbourne, Australia, July 2011. Regnum Vegetabile 154. A.R.G. Gantner Verlag KG. Koeltz Scientific Books, Königstein. 240p.

Ness, R.W.; Graham, S.W. \& Barrett, C.H. 2011. Reconciling gene and genome duplication events: using multiple nuclear gene families to infer the phylogeny of the aquatic plant family Pontederiaceae. Molecular Biology and Evolution 28: 3009-3018.

Pastore, J.F.B. 2013. A review of Vellozo's names for Polygalaceae in his Flora Fluminensis. Phytotaxa 108: 41-48.
Pataca, E.M. 2011. Coletar, preparar, remeter, transportar - práticas de História Natural nas Viagens Filosóficas portuguesas (1777-1808). Revista Brasileira de História da Ciência 4: 125-138.

Paz, J. \& Bove, C.P. 2007. Hidrófitas vasculares da Lagoa de Carapebus, Parque Nacional da Restinga de Jurubatiba, Rio de Janeiro, Brasil. Revista Brasileira de Biociências 5: 495-497.

Pellegrini, M.O.O.; Forzza, R.C \& Sakuragui, C.M. 2015. A nomenclatural and taxonomic review of Tradescantia L. (Commelinaceae) species described in Vellozo's Flora fluminensis and notes on Brazilian Tradescantia. Taxon 64: 151-155.

The Plant List. 2013. Version 1.1. Available in <http://www. theplantlist.org/> Access on 20 September 2014.

Tropicos.org. Missouri Botanical Garden. Available in <http://www.tropicos.org/Name/26100040>. Access on 5 May 2015.

Valle, J.R. 1985. Frei Veloso, Insigne Botânico Brasileiro. Conferência proferida no Instituto Histórico e Geográfico de São Paulo. Instituto Histórico e Geográfico de São Paulo, São Paulo. Pp. 3-5.

Vellozo, J.M.C. [1825] 1829. Florae Fluminensis. Typographia Nationali, Rio de Janeiro. 352p.

Vellozo, J.M.C. [1827] 1831. Florae Fluminensis Icones. Vol. 1. Lithogr. Senefelder, Paris. 153p.

Vellozo, J.M.C. [1827] 1831. Florae Fluminensis Icones. Vol. 3. Lithogr. Senefelder, Paris. 170p. 